ADDIN, Volume 10, Number 2, August 2016

\title{
INDONESIA AND THE ASEAN ECONOMIC COMMUNITY: \\ A TUSSLE BETWEEN HUMAN AND CULTURE IN THE REGIONAL MATERIALISM SUBLIMATION
}

\section{Topan Setiawan}

Sebelas Maret University, Surakarta, Central Java, Indonesia topansetiawan1974@gmail.com

\section{Abstract}

This study aimed to feel the subtle vibrations of a "project" of the ASEAN Economic Community (AEC), the buman dimension and its culture. However AEC becomes part of the life history of the nations of Southeast Asia, particularly in the visible measures, such as economic growth, the economic stability of the region or the increasing of intra-regional trade volume. It means, that we feel it in the materialist dimension, or "vibrations" a "rough". Besides, this study attempted to feel the euphoria of the other aspects. This paper will track a bit more deeply about Indonesian and its culture. Also there will be an effort to seek traces (perbaps disguised) in regional sublimation materialism "project" by AEC. Strive to be this insight led to the discovery that regional sublimation Reviews their materialism, for the next attempt to pave the way consciousness. Also, how sublimation material, it is not exactly cornered people and cultures. Another invention is the reification of culture, which it is the manifestation, in the form of Materialization on social relations, by considering it as a thing freely. Similarly, it is forgetting 
Topan Setiawan

the historical trail of goods/services. Search back on local wisdom, seems to be one way that can be taken.

Keywords: AEC, People, Culture, Capitalism, Sublimation.

\section{Abstrak}

Kajian reflektif ini bertujuan untuk mencoba merasakan getaran balus dari "proyek" kerja sama kawasan ASEAN (MEA) dalam dimensi manusia dan budaya-nya. Bagaimanapun juga MEA menjadi bagian sejarah bangsa-bangsa Asia Tenggara, utamanya dalam ukuran-ukuran kasat mata seperti pertumbuban ekonomi, stabilitas ekonomi kawasan atau volume perdagangan intra-regional yang semakin meningkat. Ini berarti kita merasakannya dalam dimensi materialis, atau "getaran yang kasar". Tulisan ini selanjutnya akan melacak sedikit lebih dalam lagi mengenai manusia Indonesia dan kebudayaannya. Juga akan ada usaha untuk mencari jejak-jejak, akan adanya sublimasi materialisme regional dalam "proyek" MEA. Dengan sekuat tenaga renungan ini akan menuntun penemuan adanya sublimasi materialisme regional itu, untuke selanjutnya berupaya meretas jalan kesadaran, bagaimana sublimasi material itu, tidak justru memojokkan manusia dan budayanya. Penemuan lain adalah adanya reifikasi budaya, yang menifestasinya berupa materialisasi atas relasi-relasi sosial dengan menganggapnya sebagai benda yang bebas dipertukarkan. Di samping itu, proses pelupaan jejak bistoris produk barang/jasa. Penelusuran kembali mengenai kearifan lokal, agaknya menjadi salah satu jalan yang bisa ditempuh.

Kata Kunci: MEA, Manusia, Kebudayaan, Kapitalisme, Sublimasi.

\section{A. Introduction}

Nearly two decades ago, in December 1997, a visionary among ASEAN member countries has agreed, and called ASEAN Vision 2020. The meeting in Kuala Lumpur Malaysia, in essentially is a marker, as well as a commitment to create of "regional strength" in South East Asia. The establishment of "regional strength" as referred in the ASEAN Vision 2020, now manifest as an AEC, that has been face us together in this time. 
Before "liven up" as we are experiencing today, AEC gets strut of deal that inflamed continuously until the ASEAN economic community can be declared. Bali Concord II in October 2003 is a premier meeting in which the ASEAN leaders declared the establishment of the AEC (ASEAN Economic Community), which is an essential goal of regional economic integration by 2020. ${ }^{1}$ In the Bali Concord II, the leaders of ASEAN are still consulted in the philosophical-conceptual level of AEC. They did not have "operational concepts" of AEC. And then at the ASEAN ministerial meeting in Kuala Lumpur, held on August 2006, they were seek to make "down to earth" the ideas as an AEC-blueprint. The other meetings have been held as a following times and their estuary is an acceleration process of the implementation of AEC. There is no doubt if finally the AEC 2015 is really enforced.

Probably, it is not any explanatory sentences needed, that blueprint of the ASEAN Economic Community (AEC) mainly formed as an economic cooperation among of ASEAN countries member. AEC became one of the latest manifestations of solidarity Southeast Asian region, which seems to want to crawl into "counter actors" for such new Asian economic powers like India and China. I think it is not an empty hope or light dream only and or counterproductive idea, but when leaders of ASEAN agreed to join their hands on AEC, along with that of competition in a variety of dimensions of life are becoming increasingly stronger.

Seems like most other social facts are created, the AEC inevitably induced polarization response. There are peoples, you call it the pessimists, who see the AEC with skepticism, with no confidence, and other manifestations of the attitude, with an estuary is not welcomed for the AEC presence. The phrase with satirical pitch expressed, and can be a marker of how the AEC is just a new way for the expansion of the market for neighbor

${ }^{1}$ ASEAN Concord II/Bali Concord II, http:// www.aseansec.org/15159 htm. 
countries product. As a result, the domestic industry may not be able to take competition, even in their own homes. AEC may be regarded as an airy corridor for the "export" of cheap Indonesian labor to more "great" neighboring countries such as Malaysia, Singapore and Brunei. Meanwhile, foreigners can be easily exploit the natural resources of Indonesia. If it happens on a large scale, then it will be cease our natural resources.

Diametrically, in the other hand, the optimist, notice that implementation of AEC as an opportunity, which in turn spur "dramatic" competitiveness of Indonesia. The Indonesia productive human resources will "force" themselves to contend and achieve competitive advantages. AEC also interpreted simply as a "money raising" in Indonesia in various sectors, which in turn boost economic growth and absorb completed our labor force, in which year by year continues to grow.

The optimist also considers that Indonesia is more ready to undergo the AEC by an assumption that the free space can be providing such benefits. For examples are; information will be more easily and quickly accessible, the domestic demand will be easily met, the production activities in the country will increase both in quality and quantity, and increase foreign exchange through the import and export tariff.

If we imagine that the neighboring countries in the aligned of AEC, whether are they overshadowed by anxieties? or are they ready to welcome "the re-establishment" of neo-liberalism that inevitably covered our region. Perhaps, for many tiny nation such as Singapore, Malaysia and Brunei did not reveal any doubt, yet how about with Cambodia and Thailand or the Sultanate of Sulu and the Philippines with their own internal political conflict? More than that may also be dragged Malaysia into the political tussle.

As we know, tracing to the history of Cambodia and Thailand turned out the fact that they still covered by the 
political tension until nowadays. The issue of Preah Vihear temple and territorial problems around them are still in dispute. Throwing historical claims regarding jurisdiction and ownership of the temple, less or more of extent will affect the bilateral relations between the two countries, Cambodia and Thailand. Though the region is now touted to be part of the kingdom of Cambodia, but Thailand seems never give up. Thailand is very tenacious defend of its historical claims.

Historical-territorial claims also did by the Sulu Sultanate, that he the Sultanate of Sulu deemed the state of Sabah (Malaysia) as one piece of territory of Sultanate of Sulu. The political tensions between Malaysia and the Sultanate of Sulu, in turn, will also affect to the bilateral relations among Malaysia and the Philippines. According to that situation, the relations among countries with the AEC framework will give a sour taste and non constructive pattern certainly.

Maybe those chores will become domestic areas of respective state governments, which do not need to be drawn as a part of this discussion. Indeed so, this paper actually wants to consider that, there is a problem also arises in other countries, not only in our country when to be exposed totally by AEC. That matters, of course, with all consequences and influences that can be caused, directly or indirectly, and even large or small scale.

When viewed more closely, there are many issues of cultural problems in the frame of territorial claims. The issue of territories or spatial is certainly connected with cultural content of the people of the region. Problem of temples, for example, is a matter of cultural and/or religious communities between Cambodian and Thai society. Cultural issues, means pertaining to the subject of culture itself, and it is signify the human with its humanity. When we drawn to the root of the problem, then humans and humanity becomes specific problem 


\section{Topan Setiawan}

within the framework of relations for countries in a "project" namely AEC.

This paper is not positioned to sharpen the diametrically position of two "group of people", optimist and pessimist, because the opposite groups, between optimist and pessimist, just a result of imaginary only. Although in reality of Indonesia it may exist and in the smallest of opposition scale only. One thing surely for us, is the AEC has been already intense all of us, slowly but surely, or even faster and will certainly give changes in various dimensions of nation life. Basically, it must be faced and of course we have to take an effort to deal with power, skill, punctilio and alertness.

\section{B. Discussion}

\section{In the Frame of Neo-Liberalism}

In the AEC Blueprint exposure by the Secretariat General of ASEAN revealed that there are five key of characteristics, which will be developed in cooperation among countries of the Southeast Asia region. The fifth characteristic are: (a) A Highly Integrated and cohesive Economy; (b) A Competitive, Innovative, and Dynamic ASEAN; (c) Enhanced Connectivity and Sectoral Cooperation; (d) A Resilient, Inclusive, People-Oriented, and People-Centered $A S E A N$; and (e) $A$ Global $A S E A N^{2}$. The characteristics and that elements, essentially is a marker, which give us sense about neoliberalism blood, flowing in the body of the ASEAN countries. The markers that clearly set out in the 2015 AEC blueprint will be explained point by point, especially regarding the scope and the technical steps necessary to achieve a predetermined goal. Although it will not be depth understanding, to get a glimpse of the characteristic, we will try to discuss at any perspectives.

\footnotetext{
${ }^{2}$ General Secretary of ASEAN, ASEAN Economic Blueprint 2025 (Jakarta: ASEAN Secretary General, 2015), p. 1.
} 
The first is economic integration and cohesion. In this case, something to be prominent is the occurrence of a single market and production base. At least, in that context, there are five movements (outflow-incoming) of materials and services are guaranteed for freedom. Even if there are tariffs, it will be issued a policy for synthesizing the rates close to zero. In other words can be said that there is a "five freedom of flow" that will frame trade flows in a "liberal projects" of AEC. The five freedom of flow is the free flow of goods, services, investment flows, the flow of labor and capital flows. To sustain the five freedom of flow, it has prepared some necessary instruments such as regulation about the tariff, non-tariff duties and liberalizes of financial services progressively, as well as other technical policies.

The second is competition, innovation and dynamism of ASEAN. This characteristic imagines how ASEAN as an entity is not be silent subject, let alone frozen. Nor as a static subject with no activities in competition and innovation dimension. So, some conceptual effort are formulated as follows; (a) engendering a level playing for all firms through effective competition policy; (b) fostering the creation and protection of knowledge; (c) deepening ASE AN participation in GVCs; and (d) strengthening related regulatory frameworks and overall regulatory practice and coherence at the regional level. ${ }^{3}$ In practice, the effort was manifested, for example, by designing and implementing a policy of competition, consumer protection, and intellectual property rights, the issuance of policies to eliminate double tax, and improving the quality and quantity of e-commerce. As an active subject, it appears that is oriented to the maximum effort how the dynamic can be back to the competition zone. Then competitiveness became a basic of thinking in policy decisions. The dynamic and innovative society, are active subjects who always competed. This nuance

\footnotetext{
${ }^{3}$ Ibid., p. 12.
} 


\section{Topan Setiawan}

dominates scattered thoughts within relation to the policy on excellence, competitiveness and freedom itself.

Third is the increased connectivity and sectoral cooperation. In this third characteristic, at least some sectors are the focus of attention, such as energy, transportation and telecommunications. The some sectors are also in line with the Master Plan Connectivity of ASEAN, that desirable to further integrate and cooperate in key sectors that complement existing Efforts towards creating an integrated and sustainable economic region, with the aim to maximize Reviews their contribution in improving the overall competitiveness of ASEAN and strengthening of soft and hard networks in the region. ${ }^{4}$ The energy sector, telecommunications and transportation are pillars of connectivity in various aspects. So, the blueprint is also shown, the measures that have to be achieved in order to anything go well.

The fourth are inclusivity, reliability and orientation of human resources (people oriented and centered). In the definition of operational, it broke downed into the five-way, which must be passed for AEC countries members. Fifth road mileage is strengthening the Role of Micro, Small, and Medium Enterprises, Strengthening the Role of the Private Sector, Public-Private Partnership, Narrowing the Development Gap, Contribution of Stakeholders on Regional Integration Efforts. ${ }^{5}$ From the various definition/ operational concept that are formed, people-oriented concept was not prominently describe to the implementable strategies, especially in the connected of the human and humanitarian relations at the regional economy relation. Just, maybe there is a " confessions " that the humans who directly involved in the micro and medium-sized of businesses (the backbone of economy), not only to the states, but larger also supporting the regional economic sustainability.

\footnotetext{
${ }^{4}$ Ibid., p. 21.

${ }^{5}$ Ibid., p. 30-35.
} 
The fifth are ASEAN worldwide or globalized ASEAN. It is a great expectation, to strengthen of regional association, yet recognized also in the global sphere. The envisioned of ASEAN might also like the EU or NAFTA who has an international prestige that every member got a " mutual reinforcement " from each others. However, the blueprint of AEC seems to be an important step to be taken, such measures based on territorial dimension. In the globally ASEAN, the most important foundation is an "affordable" in advance, that realized by making an cooperation with Japan, India, South Korea, Australia and New Zeeland. The path of cooperation outline called CEPs or Comprehensive Economic Partnerships Agreements. CEPS have been strengthening $A S E A N$ 's position as an open and inclusive economic region, and lay the foundation for ASE $A N$ to retain its centrality in global and regional engagements, where possible. ${ }^{6}$

At first glance, if we read the AEC Blueprint, as soon as possible we will realize that there is a large frame in the AEC project. The strategies prepared in using of numeric and materialistic measures. This is not an indictment, yet with our sense, we have to seek the equipoise (between material and immaterial measures), because someway AEC is real. The invisible frames, some people deem, as a frame of neo-liberalism in South East Asia region. I think it is unable to hide the numericmaterialistic measures, because ultimately that is indicates, that frame of neo-liberalism is real, as real as the AEC itself.

According to Dodi Mantra, a lecturer at Al-Azhar University, Jakarta even with direct argued how the AEC is framed by neo-liberalism. His depth searching about AEC ideology can be foundation of the arguments. Still in line with Mantra perspective, reflected in the diverse strategic step in the blueprint of AEC and the morale of the AEC itself, neoliberalism as a metamorphosis of liberal paradigm denoted the spirit of this community. Neo-liberalism assumes that the

${ }^{6}$ Ibid., p. 35. 


\section{Topan Setiawan}

market is the most effective actor determining the success of a country's economic development. On the contrary, they (the neo-lib) considers that the intervention of the state/government on the economy, through subsidies policy, for example, is an obstacle that can be distort to the market mechanisms. ${ }^{7}$

Actually, neo-liberalism is a "statement" to the state action, when the state role inflated and became counter-productive. The interference of the state is devastated the natural and fresh of free market system. Then, the path of neo-liberalism is an effort to pursue to dis-empower of the state to the market, while returning it to the commandment of the free market mechanism. For the economic history of Indonesia, during the crisis of 1998 that exposed our country, neo-liberalism seemed to be born back in the new face of "wise and authoritative" by providing analytical descriptions of the causative factor, why the crisis occurred and crashed with great.

Now, for Indonesia and the other ASEAN member countries, the neo-liberalism exposure was agreed to be more refined in somewhat wider of spatial environment, namely the ASEAN region. It was a fanfare situation mixed with anxiety at the daily notes subject of the stakeholders. And what expected from the project is, ultimately the economics growth can be permeate to all people of each country. Yet, are these all ideals will be well? For example, is there no shadow of fear at all? Armed with and adhering to the jargon that it is "the inevitable" condition, we are still swinging step towards the AEC.

Just to toss our memory, the offers of prosperity by integrated liberal trade concept within regional scope, in factually the offers were not proven true. The one of reason about establishment of a free trade zone in the North American region is to reduce welfare inequality, particularly between the United States and Mexico as well as to reduce the rate of

\footnotetext{
${ }^{7}$ Dodi Mantra, Hegemony and Discourse of Neoliberalism, (Bekasi: Mantrapress, 2011),
} p. 4-5. 
illegal immigration. In fact, NAFTA actually makes Mexico more depend on the United States. In other words, if the performance of the US economy deteriorates, by the token will be experienced by Mexico. ${ }^{8}$

The fact of failure (in above paragraph) shown us that is only involves the failure of a region, one integrated economic zone. Now we can try to posited when every country, within geographically adjacent, formed a "competition packaged by regional solidarity" what will happen in the next come days? How does the zone of economy integrated perform its activities? Is there another way of thinking, which could provide a strong argument, that everything will go fine if only all of the members play a similar role and adhere to the agreed rules of the game? Or, maybe the decision makers adhering to the theory of chance/probability theory which still gives hope for the implementation of neo-liberal system can be well? or is this some kind of a live exercise, in which we are as human beings, make ourselves as a guinea pig on devices we made?

Human being, made himself as a guinea pig, exactly some people make others as guinea pig, in the projects' achievement of prosperity. So, the "natural instrument", which is called neoliberalism, were exposed in a larger scale, which is the globally. The undertaking to massive a neo-liberal exposure are ideals to be achieved, in order to the "other men" in other hemisphere, were also enjoying the role of such instruments.

In that context, the neo-liberalism instrumentation is understood as a medium to transform the "noble ideals" of the world, namely globalization. Included in this framework is the globalization of markets. In this point of view, Manfred B. Steger, said that people or groups of neo-liberal globalists, strives to cultivate a sense of uncritical about "globalization" into the mindset of society with a great claim. The claim is a

${ }^{8}$ Joseph Stiglitz, Making Globalization Work the Next Step to Global Justice, (London: Penguin Books, 2006), p. 64. 


\section{Topan Setiawan}

huge advantage of market liberalization. The advantages are: improvement of global living standards, economic efficiency, individual freedom and democracy, as well as advances in technology that have never existed before. ${ }^{9}$

The AEC Blueprint also agree to the efforts of the neoliberal globalizes to broaden ASEAN market all over the world. $A$ Global $A S E A N,{ }^{10}$ is so obvious hints refer to the ambitions of ASEAN (with EAC) to establish, not only in Southeast Asia region, but began exploring a possibility to engage more deeply with the countries of East Asia, which is much more established, and also with any countries in central Asia or south Asia whose growth is incredible. Even, further across to the Pacific Ocean region. ASEAN is continuing to the make steady progress towards integrating the region into the global economy through a comprehensive FTAs and economic partnership agreements (CEPS) with China, Japan, Republic of Korea, India, Australia and New Zealand. ${ }^{11}$

Actually, the trace of historical to implement this global neo-liberalism, pointed out that since approximately a century ago has been prepared. So if the AEC with the ideology of neonew liberalism just implemented in 2015, in fact the ideology is awaiting a fitting moment. Mansour Fakih say that now day is the end of the era of developmentalism, a process of social change after World War II were built on the foundation of understanding to modernization. Yet, in the center of capitalism countries, the answer to speed up the pace of capitalism has long been prepared ever since the crisis of capitalism in the 1930s. That answer is the globalization of capitalism (neo-liberalism). ${ }^{12}$

\footnotetext{
${ }^{9}$ Manfred B. Steger, Globalism; The rise of market ideology, (Yogjakarta: Lafadl Library, 2005), p. 17.

${ }^{10}$ General Secretary of ASEAN, ASEAN Economic Blueprint 2025, (Jakarta: Secretary General, 2015), p. 35.

${ }^{11}$ Ibid., p. 35.

${ }^{12}$ Mansour Fakih. Jalan Lain, Menifesto Intelektual Organik, (Yogyakarta: Insist Press, 2002), p. 184.
} 
Thus, some final paragraphs in this segment, inevitably, I have to associate the "psychological" atmosphere of AEC, with the concept of "frame", a thought by Martin Heidegger, a German philosopher. "Framing" or in Germany is Ge-stell, (can be interpreted as a skeleton also ), in Heidegger's perspective provides supposition as a "bookshelf", that means he wants to propose an affirmation human being is always thinking by using the "framework". ${ }^{13}$ In the relation to the AEC, Heidegger gives all of us awareness that the neo-liberalism finally is a "frame" of public economic activities in the countries of Southeast Asia. So, what can be captured from our presence of mind, that all of nations in Southeast Asia have been 'framed' by neo- liberalism?

Thus, if we deemed that the national and regional economies are building, so the concrete bones framed by, is neo-liberalism. Then, if we are rethinking about the frame, we will find an application of neo-liberalism by the government, likely installing the dangerous "barbed wire fences". Then, Martin Heidegger said that "In which the framing is in power, that is a place, where the danger in the most obvious means". In other words the danger threatened the world now is the frame itself. ${ }^{14}$ Because the frame is like a barbed wire fence (barbed wire fence has directions of sharp in and out), then the danger of framing is double.

The first direction is the government itself. The government seemed have no role, stripped of its power to its citizens, who in the fence border, by regulation makers that are pro neoliberalism. Please imagine a government totally meaningless apart as a tool only, of the capitalist ideology of neo-liberalism. So the frame set up by the government has been framed the own

${ }^{13}$ Francis Lim Chin Choy, SJ Membingkai (Ge-stell), Sejenis Pembusukan Pandangan terhadap Dunia, dalam Al Andang, L Binawan (ed.), Korupsi Kemanusiaan, Menafsir Korupsi (dalam) Masyarakat, (Jakarta: Kompas, 2006), p. 69.

${ }^{14}$ Ibid., p. 53-54. 


\section{Topan Setiawan}

roles in this country. But, the existence of government is not be negated, however utilized under guidance of the capitalists, who held neo-liberalism ideology.

The second direction is, the danger will be experienced by the people, when they are allowed to compete freely in their position as a society, both of consumers and producers. In the extreme words can be said that society in particularistic level have been entered to the atmosphere of survival at the fittest. There is a condition of the people who are diametrically sharp difference, because the rich get richer one and the poor get poorer one. Indeed, generally GDP will grow up, but not followed by evenly spread of wealth distribution. And a large number of people became poor. Mexican The experience Mexico within NAFTA framed, least gave us clear proof about it. During the first decade of NAFTA, the economic growth of Mexico are bleak, only 1.8 percent on a real per capita. In fact, it was better when we compared to another countries of Latin America, but when we compared to the economic growth achieved by Mexico during the period of 1948-1973, the growth rate of 1.8 percent is very bad, because in that period the average of growth reached at 3.2 percent. $^{15}$

Back to the Ge-stell of Heidegger, framing is the way used by humans being objectify the world and his experience, the object has been framed become available for the cultivation and manipulation of human beings for a specific purpose. So it looks like that framing is the ideal for human being to nature dominate. ${ }^{16}$ It means that neo-liberalism is a real frame for the manipulation of human purpose, as Heidegger discoursed by theory of Ge-stell.

${ }^{15}$ Joseph Stiglitz, Making Globalization Work. The Next Step to Global Justice, (London: Pinguin Books, 2006), p. 64.

${ }^{16}$ Francis Lim Chin Choy, SJ, Membingkai (Ge-Stell), Sejenis Pembusukan Pandangan terbadap Dunia, in Al Andang, L Binawan (ed.), Korupsi Kemanusiaan: Menafsir Korupsi (dalam) Masyarakat, (Jakarta: Kompas, 2006), p. 54. 


\section{Under the Sublimation of Materialism}

When we look together to the AEC blueprint, at point $\mathrm{D}$ said about the concept of a Resilient, Inclusive, People-Oriented and People-Centered ASEAN. ${ }^{17}$ At first phrase, people-oriented, it can be perceive as community involvement in the activity of the AEC, which includes humans and humanity itself. However, after we read more detailed, it was not encountered a signal go there. There is no indication that human and humanity, which incidentally is the subject of neo-liberalism itself, getting the attention. But the fully attention is just understanding the subject as a market merely.

The explain paragraph for points of a resilient, inclusive, people-oriented, and people-centered ASE $A N$, in fact not only within the human dimension and humanity, but also no explanation at all, regarding the position of "humanists" of the humans themselves. Promote entrepreneurship and human capital development by creating a more conducive environment for entrepreneurship through the ASE AN On-line Academy; and enhancing human capital development for MSMEs, in particular youth and women. ${ }^{18}$ It seems that, when human beings were dissipated into the atmosphere of neoliberalism, the efforts of human resource development also oriented to the materialism. It is a human resources placement at the production structures, a placement that positioned the human beings as a production factors, and became something important to be used and rivalry. This is a placement human resources at the physical/material level, by abandoned the psychological aspect.

In view of Feuerbach, human (who trapped as a factor of production via neo-liberalism) is human with characteristic like as mechanical materialism. Furthermore, he said the important thing for human beings were their business and not their minds,

${ }^{17}$ General Secretary of ASEAN, ASEAN Economic Blueprint 2025, (Jakarta: General Secretary, 2015), p. 30.

${ }^{18}$ Ibid., p. 31. 
because knowledge as only tools for achieving the success. Humans (in this contact) as a natural being (Gattung). ${ }^{19}$ This view explains that human effort into eminent position, glorious, and became the foundation for success, while the knowledge and skills positioned no more than just a tool/medium or medium only. Common sense or intelligence finally is no more than just a tool. If humans within the framework of "AEC peopleoriented", getting exposure of self-development architecture, development of skills and knowledge, so it is means in order to meet the needs of a factor of production merely. This phenomenon (in my point of view) is an explanation of mechanistic materialism, by Feuerbach. Human beings are most likely the robots, which helps other machines completing a production of goods and services.

It may be very exciting to see the Indonesian within Marxian framework. According to Marx, the whole of human life is determined by the framework of economical relations. Overall, any activities or spiritual activity, aesthetics, theology, ethics and even science, have characteristic as a superstructure and that is a residue from the pattern of economic relations. The economic relations are determined by history. Man, still in Marx thought, basically as a worker (homo laborans or homo faber). In his capacity as homo laborans basically, the work itself is something stolen from the man himself. So, according to Karl Marx, the human factor or labor (human) held different positions by other factors of production. The man placed in a position of variable factors. Perhaps, it because the portion required in the production process "is very easy to set", with the maximum efficiency approach in possibly. This elasticity has shown the position of humans as a variable factor in the process of production of goods and services.

Furthermore, Marx said that there are two strong factors working in a production process of goods, namely a) the forces

\footnotetext{
${ }^{19}$ Harun Hadiwijono, Sari Sejarah Filsafat 2, (Yogyakarta: Kanisius, 1980), p. 119.
} 
are material productive called the forces of production, this includes: (1) raw material (2) the means of production (work tools, machines, etc.) (3) skills/ability to work and (4) work experience. 2) the relations - the relations of production, which is the relationships between people in the production process or the social relations of production. ${ }^{20}$

We can see that in the two of these factors, the man (human) occupied by two positions at once. In the position of forces of production, man no more than human labor, so it should be designed along with the attributes of required in a production process, in example, proficiency/skill and work experience. Meanwhile, in the position of social relations, the inter-personal skills, within now day is often referred to as soft skills, humans are also required to master the soft skill.

Using sublimate way of thinking in terms of psychology, it seems relevant enough to explain how neo-liberalism sheath the AEC and treats the human resources in the reasoning of materialism. As we all know at the realm of psychology, there is a self-defense mechanism. One of such mechanism is called sublimation. Sigmund Freud defines sublimation is self defense intended to prevent or relieve anxiety by altering and adjusting impulses, that cause anxiety in the form of behavior that is acceptable and even valued by the community. In short, sublimation is an unconscious process where the libido is indicated or changed him into a form of distribution more acceptable. ${ }^{21}$ For example is the aggressive impulse from someone channeled into activities compete in sports, so he will found a way for the disclosure of the aggression, and as an addition, he can earn rewards when he was excel in the field of sport.

${ }^{20}$ Marx, The Materials Forces and The Relations of Production, to the Critique of Political Economy, in Parson, et. al. Theories of Society, (New York: The Free Press, 1965), p. 136- 138.

${ }^{21}$ Sigmud Freud, Teori Seks, (Yogyakarta: Jendela, 2003), p. 166. 
Turned back again to the man's position in the frame of AEC neo-liberalism, exploring the architecture of AEC carefully, we will find how the human (human resources) has been "materialized" in so subtle way. Why human has been materialized? We can shown by the empowerment model that creating a more conducive environment for entrepreneurship through the ASEAN On-line Academy; and enhancing buman capital development for MSMEs, in particular youth and women. ${ }^{22}$ The empowerment strategy undertaken by the architects of neo-liberalism in the frame of the AEC is the positioning strategy of the human factors of production in order to boost the quantity of goods production. In Marx words, man is a variable factor confined in the forces of production and social relations.

Extremely, the bidden agendas, (in the management of human resources of economic liberalism atmosphere), are explore or desire as much as possible the use of labor at goods production. The desires of human exploitation (in example, the working system of out-sourcing, labor contract system in certain time, etc.) may not be rugged. We can only saw the sublimation impulse of exploitative practices as siding with the workers. The architects and capitalists feel anxious if the workers did not become a factor of production as they are projected. So, sublimated by giving any various stimulus and raise the minimum wage, for example, can be create a domino effect leading to a maximum benefit of the capitalists. Just look at the cyclical process of public buying power has been increased (stimulus, raise minimum regional wage), causing the buying power rises, then demand is also raising, the entrepreneur/owner of the capital will have a significant profit. The great advantage of the capitalists can be foster of investment by re-investing in various project lines, then the GDP also raised, sparked an increase in

${ }^{22}$ General Secretary of ASEAN, ASEAN Economic Blueprint 2025 (Jakarta: ASEAN General Secretary, 2015), p. 31. 
the ability to buy, and demand rises back, and so on. This policies model finally can be accepted by the community.

In turn, the characteristics of human beings who fill the position of a variable factor of production are a pragmatic materialist, with results orientation (goods and services) as much as possible. So, people oriented in the AEC blueprint, will also throw in the education sector network of neo-liberalism that threw it to the free market. The role of the State to intervene care of education should be reduced, subvention of education costs should be reduced or possibly to be amputated, so consequently the cost of education can be more expensive and the product resulted very completely in accordance with the demands of the market. The interests of the capitalist of neo-liberalism, in this case, is to obtain a highly professional workforce, has a high skill and just paid them for very-very minimum cost.

Well, finally at our face will be presented just the professionals who are pragmatic and opportunistic. They are may be extremely smart, has the high degree, has adequate of hard skills and soft skills, yet in another perspective they were basically a result of sublimation process of materialism. They will be taken away from the characteristics of idealists who still want to think of this country.

Even though the human resources have a high skill and intellectual, they are only apart from the giant machine of neoliberalism and positioned as a variable of production factor only. It became possible because the tradition of thinking in neo-liberalism is preparing into all aspects of life, including at education aspect. According to one of the liberal thinkers of the world from the Philippines, Julio Teenhankee, traditions of thought can be identified into six fundamental principles. The tradition of liberal thinking that gives ample room for hidden agendas sublimation, so it can be accepted by the community/ country. These six fundamental principles by Julio Teehankee are 
as follows: ${ }^{23}$ (a) Individualism; The liberalist believe that individual is very important things. So, the all policies decided are aimed to provide a freedom and personal rights, because individualism is more meaningful than collectivism. (b) Rationalism; the liberalist look at view that the world is rationally structured; whose can be understood by requires logically reason. The orderly world stimulate critical continuous search. (c) Freedom; for liberalists, there is nothing more glorious than freedom. Freedom is ability to reason, nor did congruently with determination of heart. (d) Responsibility; liberalism is freedom (at its base) accompanied by responsibility. Not unlimited freedom, which became very wild. (e) Justice; for devotees of liberalism, justice is a moral value, within provides an opportunity to individuals a freedom in order to fully competition and reach what is truly their rights. (f) Tolerance; The liberalist also believe in tolerance as a gesture of respect or honor viewpoints and behavior patterns of other individuals. Even if the opinions or actions of another individual is not certain favored, the tolerance still they hold as the foundation of the harmony of life and also to uphold freedom itself.

The liberalist thinkers recognize that individual freedom is the most important thing, because with the freedom of the six principles above can be achieved. And received affirmation from Fukuyama also glorifies liberalism. Francis Fukuyama who believes that liberalism is the final of history and it is impossible to defeat by another ideology, because the liberal is an ideal ideology and accordance with humans. ${ }^{24}$ Almost two decades ago, Fukuyama's imagination about the romance of "eternal glory" of the democratic-liberal (capitalist-neoliberal), has been repercussion and disseminated. The story started from the fact

${ }^{23}$ Julio Teehankee, "Equity and Justice in a Globalized World: A Liberal Review” in http:// www.fnf.phlseminars/reports/equity-justice-in globalized-worlreview.htm

${ }^{24}$ Francis Fukuyama, "The End of History?" The National Interest, Volume 16, Summer 1989 in Irving Kritol, et. al."Memotret Kanan Baru” (Yogyakarta: Kreasi Wacana, 2001), p. 49-122. 
that the economic and political world in the frame of the free market (free market), was received most governments of the world at that time.

Moving on to the other sublimation practice, our interest sucked up by more intensively observes the issue of energy. The policy about free flow of capital and investment, provide the option of utilization in various sectors, including "the excellent" is the energy sector. In the energy sector, the AEC Blueprint take counsel superficially of the electricity, gas pipeline interconnection, coal, renewable energy, energy conservation up to the issue of civilian nuclear energy. ${ }^{25}$ The description in the AEC blueprint especially in energy scope has appeared the spirit of AEC is materialism. The relationship between the process of energy production and its environment, were not mention over there.

In this framework, it is possible the implementation of several projects such as the interconnection of electricity networks, launching of bio-based fuels or the implementation of mining concessions are would potentially caused of sociocultural and environmental imbalances. For example, the projects can be marginalize communities that are already exist, threatening for food security, juggling for the forest and agriculture into the industrial zone, water pollution, soil erosion and so on. The cultural issues, people and the environment as above, are not properly addressed, so the journey road to overcome the problems that inevitably arise, are not prepared.

The endogenous passion of liberalism is an exploitation of natural resources (and even human) totally, in order to achieve maximum profit conditions. Passion is actually not allowed if leaving environmental ethics and local wisdom that already exists. If the only passion was explosive and have a negative impact, and cause a resistance in the community, there

${ }^{25}$ General Secretary of ASEAN, ASEAN Economic Blueprint 2025, (Jakarta: ASEAN General Secretary, 2015), p. 25. 
is an attempt to sublimate it's with an actions more accepted by society. In this case, they hold the programs like "social awareness" within various activities, holding community leader/ traditional leader (possibly with certain transactions), using a workforce of around an investment location (although for example, unskilled and low-wage) and constructing necessary facilities/infrastructure. Although people mobilization as an elastic variable factor of production have been done, that is exactly more socially acceptable. But we can see some of companies neglect the ex-mine and damaged land.

Providing the foundation of liberal pressure to freedom of individuals to determine their own concepts of goodness, is a failure of liberalism in the face of liberated itself, within individuals drained of standards to make their own choices. It is a fact that actually suppresses freedom itself by rationalization process, by the purpose of consumption, and by sociological power urged. For Ross Poole, it adds to the belief of how the ideology of liberalism is nihilism. ${ }^{26}$

The end of this segment will provide an emphasis on the symptoms truly we are feeling. The symptoms were present together with the central goal in which dominates the AEC Blueprint that is a material triumph. This symptom can be modeled in conceptual overture in order to embrace ASEAN people and also put its view in qualitative dimension. The glorifying human project, is a project that more acceptable in the prevalence of community life. This is a manifestation of the psychological concept of sublimation. The human existence is elevated (within the framework of neo-liberalism, of course) and then destroyed 'back into a mechanical work-robotic system. That is aimed to the production of goods and services as abundant as possible. Finally the "genecology" objectives of neo-liberalism ideology (that is material), can we feel subtly

\footnotetext{
${ }^{26}$ Ross Poole, Moralitas dan Modernitas, Dibawah Bayang-bayang Nibilisme, (Yogyakarta: Kanisius, 1993), p. 72.
} 
through the symptoms that are sent through the various concepts, as stated in the AEC Blueprint.

\section{Communication, Culture, and Unity of Signs}

After all, AEC is one of many forms of international relations, between one country and another with different in many ways. There are many possibilities will be occurred in many aspects of the relationship. The one basics thinking fairly representative to observe international relations is critical theory. Historical traces of this approach show that the critical theory began to debut in the arena of international relations, about almost four decades ago, around the 1980s. Critical theory helps us to think more deeply about the real practice daily life, and the relation between the theory and the way or pattern we are act. ${ }^{27}$

Within critical theory, appeared several assumptions in relation of the practice of international relations, one of which is the ideology and culture. The ideology and culture is a special force, and can strategic support or otherwise oppose the economic and social order prevailing. ${ }^{28}$ Ideology and culture arrested a special attention within the framework international relations; in this context is the relationship among Southeast Asian countries in the AEC frame. Although the AEC blueprint does not imply awareness of cultural dynamics in each country, yet the critical theory can be capture and bring us, to explore the probability space impacted on the cultural life of the AEC society.

Using the conceptual framework of AEC foothold, the domino effect on the free flow of investment and capital that may be occurred is its intersection with the culture of this nation. The one possibility that could occur in that policy is growth of industries, both producers of goods and services. A further process is the flow of foreign workers streamed into Indonesia, especially experts with high professionalism.

${ }^{27}$ Jill Steans \& Lloyd Pettiford, International Relations: Perspectives and Themes, (London: Pearson Education, 2001), p. 101.

${ }^{28}$ Ibid., p. 102. 
Levels of managerial, core personnel who determine the policy/direction of the company is very likely to come from the member countries of the AEC which has advanced and highly competitive in terms of human capital. Many neighboring countries such as Singapore and Malaysia, for example, have relatively high competitiveness. Regarding the competitiveness of Indonesia's human resources, there is interesting news in a national newspaper Kompas, the issued at November, 25th 2015. Kompas daily reported that the Institute of Management Development (IMD), a top-tier business education institution in Switzerland, has conducted a research on human resources. A survey entitled IMD World Talent Report 2015 has been successful rank of personnel skilled and talented. And, in that project, Indonesia is one of the research subjects, along with 60 other countries in the world. In the report explained that Indonesia fell 16 ranks, from the beginning of the $25^{\text {th }}$ rank in 2014, being ranked 41th in last 2015. This position is so distant from the position of neighboring countries such as Singapore, Malaysia and even Thailand.

The influx of foreign professionals to Indonesia in ever greater quantities, as the free investment in this country cannot ignite cultural issue, as small and simple as whatever it is. For example, in the aspect of communication problems, it actually becomes very important in the process of sending each message in order to understand by other person. Moving on from the definition of communication by Larry A. Samovar, Richard E. Porter, and Nemi C. Janen can be identified problems that may arise in this activity. In his book titled Understanding Intercultural Communication, Samovar et.al defines communication as "Communication is defined as a two-way, on-going, behavior affecting process in the which one person (a source) intentionally encodes and transmits 
a message through a channel to an intended audience (receiver) in order to induce a particular attitude or behavior". ${ }^{9}$

From the above definition, it appears communication scholar has an ultimate goal to influencing the action of communicant. But in the context of the liberalization of the labor by AEC, it clearly appears one of noises in the communication process, such as the language barrier. So, the purpose of influencing the communicant behavior cannot be achieved. As it was realized in the works, the aspect of interpersonal skills (which one aspect is communication) is very important in helping to maintain the corporate culture. AEC in relation with the language issue, for example, whether the government is consistent to regulate foreign workers who work in Indonesia should be able to speak Indonesian. This, might assume that there is trivial, but what about the Japanese, for instance, is so firmly staunch armored tub to keep oblige foreign workers learn Japanese, while working over there.

In the Act Number 24 of 2009 on the Flag, Language, and the State Emblem and Anthem, have governed the use of Indonesian in the contract of employment in State Corporation, private company and others. Then, that is implemented by Permenakertrans (ministry of labor regulation) number 12 of 2013, which set the Indonesian language obligations towards foreign workers, while working in Indonesia. The President Jokowi cabinet, namely work cabinet, in this case the labor ministry has been deconstructed of Permenakertrans No. 12 of 2013, by issuing a new judicial policy, called Permenaker No.16/2015. Though conditions were explicitly referred to the article 26 paragraph (1) letter (d) Permenakertrans No. 12 of 2013 concerning procedures for used the foreign workers. It has been mentioned in this article four conditions of foreign workers employed by the employer, one of which 'can communicate

${ }^{29}$ Andrik Purwasita, Komunikasi Multikutural, (Surakarta: Muhammadiyah University Press, 2003), p. 98. 


\section{Topan Setiawan}

in Indonesian'. The deconstruction above even sparked a new problem, an effort that may make it easier but it seemed odd. In the perspective of psychology, the ministry of labor of Republic Indonesia did displacement from the original problems, which would lead to new problems. The ministry of labor regulation (Permenaker) No. 16/2015 just did not address the Indonesian language for foreign workers. Then, what happens is? The migration of foreign workers (Chinese) which may be unskilled, cannot speak Indonesian and perhaps also their illegal arrival became real and in large scale.

Pursuant to Okky Asokawati, members of the House of Representatives of the PPP, the ability to speak Indonesian by foreign workers should be an absolute requirement when working in Indonesia. In addition to respect the dignity of our nation, Indonesia, President Jokowi as if not aware that due to the elimination of the obligation Indonesian requirements for foreign workers has been distanced of nawacita. ${ }^{30}$ The gate of AEC, can be opened widely in line with the fact of "dodge impossibly", but the government should not be resigned to simply establish a rule under Liberalism gunpoint. Minimal in this context is still requiring foreign workers to master the Indonesian language. When foreign workers are unskilled, that are getting hurt local workers that the majority of graduates of elementary school and junior high school. Ironically, promise to open 10 million jobs for the people of Indonesia would be enjoyed freely by foreign workers. ${ }^{31}$

We all know language is part of culture. Language is a symbol of verbal communication, which is either spoken or written language. ${ }^{32}$ So take a foothold one of the assumptions in critical theory in international relations, namely the ideology

${ }^{30} \mathrm{http} /$ /www.hukumonline.com/berita/baca, (accessed, 12 Mei 2016, at 09.35 p.m.)

${ }^{31}$ Ibid.

${ }^{32}$ Dani Vardiasyah, Pengantar Ilmu Komunikasi: Pendekatan Taksonomi Konseptual (Bogor: Ghalia Indonesia, 2004), p. 24. 
and culture can oppose or support the economic and social order that is valid, then the language as a symbol of communication verbal, "destroyed" by the desire of the capitalists who boarded the neo-liberalization of the MEA. Project "destruction" was so strong that the government-felt need to help the project through Manpower Regulation No. 16 of 2015.

In this discussion, it becomes very interesting to see the language in the "it's suffering", in example, when the language included the kind of atmosphere of reification of culture. In connection with the reification of culture, a thinker neo-Marxist from United States of America, Fredric Jameson said there are two important quite meanings. First, the reification as the transformation of social relations into objects (the transformations of social relations into things) or objectify of social relations. The objectify perspective was perceive a social relations (cooperation, affection, care, recreation and so on) as a commodity can be bought and sold. ${ }^{33}$

Second, the reification as the elimination of traces of production of the object itself (the effacement of the traces of production from the object itself). When the people consumed, they are forgetting how the product was made, forget too (though temporarily) the people who created the product, as well forget the poor people (who cannot consume these goods). If not forgotten could be disrupt the process of consumption or even damage the intimate space of ownership. ${ }^{34}$

The objectify activity can be found at legal products (product of law), as you can see at Ministerial Regulation No. 16 of 2015, which did not see the cultural elements (in this case is Indonesian Language) as something very important in the production process. Its existence could be replaced by,

${ }^{33}$ Fristian Yulianto, "Budaya dalam Cengkeraman Kapitalisme Transnasional : Membaca Realitas Sosio-Kultural bersama Fredric Jameson, dalam Al Andang L Binawan (ed ), Korupsi Kemanusiaan, Menafsir Korupsi (in) Masyarakat, (Jakarta: Kompas, 2006), p. 44.

${ }^{34}$ Ibid. 


\section{Topan Setiawan}

for example, knowledge and proficiency/skills (hard skills in a particular field), and it was regarded as a thing (because of the skill is inherent in the body/individual figure) that can be traded. Man with knowledge and skills to be a thing, then it can be traded so. Industrial goods and services in Indonesia can buy an object called a human being and its skills/aptitude, to be used as variable factors of production.

While, the activities of the elimination of traces of the production of an object/service, for example appears in (especially) consumption pattern of the bourgeois/rich man, who saw the object as satisfying the needs of goods only. An abundance of money makes them "forget" or cannot think about other dimensions behind the goods they consumed. Included is not thinking, that parties outside that not being able to access these products. This explains, as though they were present just like that, without a long production process that actually leaving the trail over there. Man, at this point, becomes man who breakaway aspect beyond the self and the object, that are fused with itself in the pattern of consumption.

Of the two essential meanings about cultural reification above, further, Fredric Jameson admits appeared another meaning that is no less important. The other side of a product, is its existence of which was not forgotten. Because the product can be special by a "signature" from producers. The authors sign a book of his creation, the artist represents herself in a signature that she affixed on the shirts, on the hijab, or present themselves in a joint selfie with fans. That all things are reflect an " imaginative presence " of the maker of the product. In that context, it is not to ruin the intimate relationship between the user and the product, had been framed by a pattern of consumption.

Thus, our imagination says, as though, there is separation between consumers and producers, within which there is "amazement" of consumers before the producers, how the production process was so intense and complicated. Here 
comes sub-alternity, that kind of feeling inferior (consumers) in the presence of people or cultures that are considered more superior. ${ }^{35}$ Among the consumer and the producer, appeared "specialization", distinguishing between producer culture and consumer culture. So, in the AEC, when infestation freely in and then the industries stand up freely, the cultural atmosphere between consumers and producers, such as falling above will appear. It was, at once be a special issue today.

If from the standpoint of language only, the AEC has been "beat out" the cultural sovereign of republic of Indonesia. Then, how about the other dimensions of life? In the case of foreign people working in Indonesia, the policy makers have been 'simplify' the issues with the Indonesian verbal communication, and replace it with a non-verbal language, such as sign language. So, communication between local labor and foreign workers will be helped by this non-verbal language, although that language is also certainly be different from each other. In this context, the signs to be "united" in that communication form.

While, there are other ideas that each item of language (words, sentences, phoneme, morpheme, etc.) exists to solely fulfill a function, which generally is a function of communication. The idea, then superimposed on another idea, that none of the language elements can be evaluated, if not in relation to other elements. The idea of the relationship was the basic of the theory, that language is a system of relations. ${ }^{36}$ Its relationship with government policy, with not required to master Indonesian by foreign workers, means the government has underestimated the linguistic relation system.

In particular scale, the foreign workers linguistic reality has been dominated our local culture (language), which in the view of Soedjatmoko, our country has a receding risk status,

\footnotetext{
${ }^{35}$ Ibid., p. 45.

${ }^{36}$ Octavio Paz, Levi Strauss, Empu Antropologi Struktural, (Yogyakarta: LKiS, 1995), p. 8-9.
} 
to the position of mere consumers of cultural products from foreign civilizations. So, the solutions at a cultural level according to him is, the country can find the key from the spirit, motivation, and personal appearance are used to draw up the pattern of development in new and different, so it needs creative adjustments of the elements of the identity of cultural premises. ${ }^{37}$ The thought of Soedjatmoko, are relevant to the context of Indonesia contemporary. The international relations in the frame of the AEC regionally, for example, it arise a serious risk, as pointed out by Soedjatmoko, some decades ago. Actual case that had become a national scale, the pros and cons of the Ministerial Regulation number 16 of 2015, would be required a creative adjustments from the government. And in this case, a feasibly simple action is enforced the rules of compulsion the Indonesian language mastery, for foreign workers who want to work to make a living in Indonesia. Moreover, the population of our country is the largest among members of the AEC, and it is a tremendous market. Will we simply be a "mere consumers", by which becomes a loser nation?

\section{Conclusion}

With the tempestuous spirit of "inevitable" the AEC present and come to us with a "threat" of neo-liberalism. Still with the spirit of "inevitable", the government also welcomed with a blend of feelings between anxious, pessimistic and optimistic. One more, still with the argument of "inevitable", similarly several preparations are designed and built in the rules models, at both the president (presidential decree), as well as ministerial level (ministerial regulation).

The fulcrum of attention being sucked to the promises of material prosperity by AEC, actually forget about the others. Hereinafter, this "musing" is trying to strengthen our sense,

${ }^{37}$ Idy Subandy Ibrahim, Dari Nalar Keterasingan Menuju Nalar Pencerahan, Ruang Publik. dan Komunikasi dalam Pandangan Soedjatmoko, (Yogyakarta: Jalasutra, 2004), p. 130. 
receiving the subtly hidden of symbol (and perhaps any one saw not a hidden symbol, but it is the activity that so bare, though not naked perfect), that the mega-project of "unification" the ASEAN region by AEC, has been "hurt" the human dimension and its culture. The enchantment (in possibility) of welfare exposure by AEC, tend framed in materialism.

This paper has finally found awareness of the AEC, it is a "unity of various symbol" framed by neo-liberalism ideology. The AEC blueprint reflects a very strong aroma of that ideology, which then responded with policies of the government that "one tone" with the spirit of neo-liberalism. There are so delicate process called material sublimation in implementation of AEC with all paraphernalia of its economic projects. The sublimation expected a good reception from the whole of society with respect to anything of the AEC. Including the impact of investment freedom and freedom of capital, that led to the establishment of enterprises in Indonesia.

Lastly, there is a process called reification of culture, which its manifestation such as: the first, attempt to objectify or materialization at sociological relations. Social relations are considered as an object that can be freely given in exchange. The second, the process of forgetting historical traces of goods and services. This is a decisive decision to take the distance among producers, consumers, and also with the people around who have limited access. The third, is sub-alternity, which looks so superior producers and the product comes with a "special signature", so the forgetting process of the product, be well forgotten. Then, dealing with a clear stance is one of anticipation model, while determined to remain as the real Indonesian. 


\section{REFERENCES}

Binawan, Al Andang L, Korupsi Kemanusiaan, Menafsir Korupsi (dalam) Masyarakat, Jakarta: Kompas, 2006.

Fakih, Mansour, Jalan Lain; Manifesto Intelektual Organik, Yogyakarta: Insist Press, 2002.

Freud, Sigmund, Teori Seks, Yogyakarta: Jendela, 2003.

Harun, Hadiwijono, Sari Sejarah Filsafat 2, Yogyakarta: Kanisius, 1980.

Ibrahim, Idy Subandy, Dari Nalar Keterasingan Menuju Nalar Pencerahan; Ruang Publik dan Komunikasi dalam Pandangan Soedjatmoko, Yogyakarta: Jalasutra, 2004.

Kristol, Irving. et. al. Memotret kanan Baru, Yogyakarta: Kreasi Wacana, 2001.

Mantra, Dodi, Hegemoni dan Diskursus Neoliberalisme, Bekasi: Mantrapress, 2011.

Parson et. al., Theories of Society, New York: The Free Press, 1965.

Paz, Octavio, LEVI-STRUSS, Empu Antropologi Struktural, Yogyakarta: LKiS, 1995.

Poole, Ross, Moralitas dan Modernitas: Di Bawah Bayang-bayang Nibilisme, Yogyakarta: Kanisius, 1993.

Purwasito, Andrik, Komunikasi Multikultural, Surakarta: Muhammadiyah University Press, 2003.

Sekretariat Jenderal ASEAN, ASEAN Economic Blueprint 2025, Jakarta: Sekjen ASEAN, 2015.

Steans, Jill \& Pettiford, Lloyd, International Relations: Perspectives \& Themes, London: Pearson Education, 2001.

Steger, Manfred B, GLOBALISME, Bangkitnya Ideologi Pasar, Yogjakarta: Lafadl Pustaka, 2005. 
Stiglitz, Joseph, Making Globalization Work the Next Step to Global Justice, London: Penguin Books, 2006.

Vardiansyah, Dani, Pengantar Ilmu Komunikasi, Pendekatan Taksonomi Konseptual, Bogor: Ghalia Indonesia, 2004.

ASEAN Concord II/Bali Concord II, http://wmw.aseansec. $\mathrm{org} / 15159 . \mathrm{btm}$

Julio Teehankee, "Equity and Justice in a Globalized World: A Liberal Review", at http://www.fnf.phlseminars/reports/equetyjustice-in-globalized-worldreview.htm

http:/ /www.hukumonline.com/berita/baca/lt55dabf7c14f38 


\section{Topan Setiawan}

Halaman ini tidak sengaja untuk dikosongkan 